\title{
Critical heat flux in a closed two-phase thermosyphon
}

\author{
Konstantin Ponomarev ${ }^{1, *}$, Anastasiya Islamova $^{1}$, and Feoktistov Dmitry ${ }^{2}$ \\ ${ }^{1}$ National Research Tomsk Polytechnic University, 634050 Tomsk, Russia \\ ${ }^{2}$ Institute of Thermophysics Siberian Branch, Russian Academy of Sciences, Lavrentiev Ave. 1, \\ Novosibirsk, 630090, Russian Federation
}

\begin{abstract}
A closed two-phase thermosyphon experimental setup with the possibility of recording the coolant and its vapors temperatures was developed. We proved the use of the V. M. Borishansky and S. S. Kutateladze correlations for the determination of the critical heat flux in closed two-phase thermosyphons with the ratio of their internal diameter to the length of the heat supply zone in the range of $1<d_{\text {sнym }} / L_{u}<2$.
\end{abstract}

\section{Introduction}

It is known [1] that the heat exchange rate in a closed two-phase thermosyphon (CTPT) depends on the heat flux $\mathrm{q}$. Under conditions of attaining critical values of $\mathrm{q}$ and higher than $\mathrm{q}_{\mathrm{cr}}$, the heat exchange rate decreases. The minimum thermosyphon filling ratio depends on the critical heat flux $(\mathrm{CHF})$, geometric dimensions (internal diameter, evaporator length) and coolant thermal properties [2].

Based on the analysis of known dependences [2-18] for the critical heat flux calculation they may be conditionally divided into two groups based on different concepts. The first concept correlations [7-12] are based on the achievement of the vapor velocity limit, at which the hydrodynamic instability of the liquid-vapor interface and the entrainment of the descending liquid part by an ascending vapor stream occur. The correlations are based on the numbers: Wallis [7-10] and Kutateladze [11, 12]. The second concept correlations [1318] are based on the heat transfer crisis from the heating surface to the liquid (the vapor film occurrence between the wall and the coolant). These correlations are based on the stability criterion $\mathrm{K}$ of a two-phase wall layer [1].

The aim of this work is to determine the critical heat flux in closed two-phase thermosyphons with the ratio of their internal diameter to the length of the heat supply zone in the range of $1<d_{\text {внут }} / L_{u}<2$.

\section{Results}

The scheme of the experimental setup simulating the work of the CTPT is in Fig. 1.

\footnotetext{
* Corresponding author: kop.tpu@gmail.com
} 


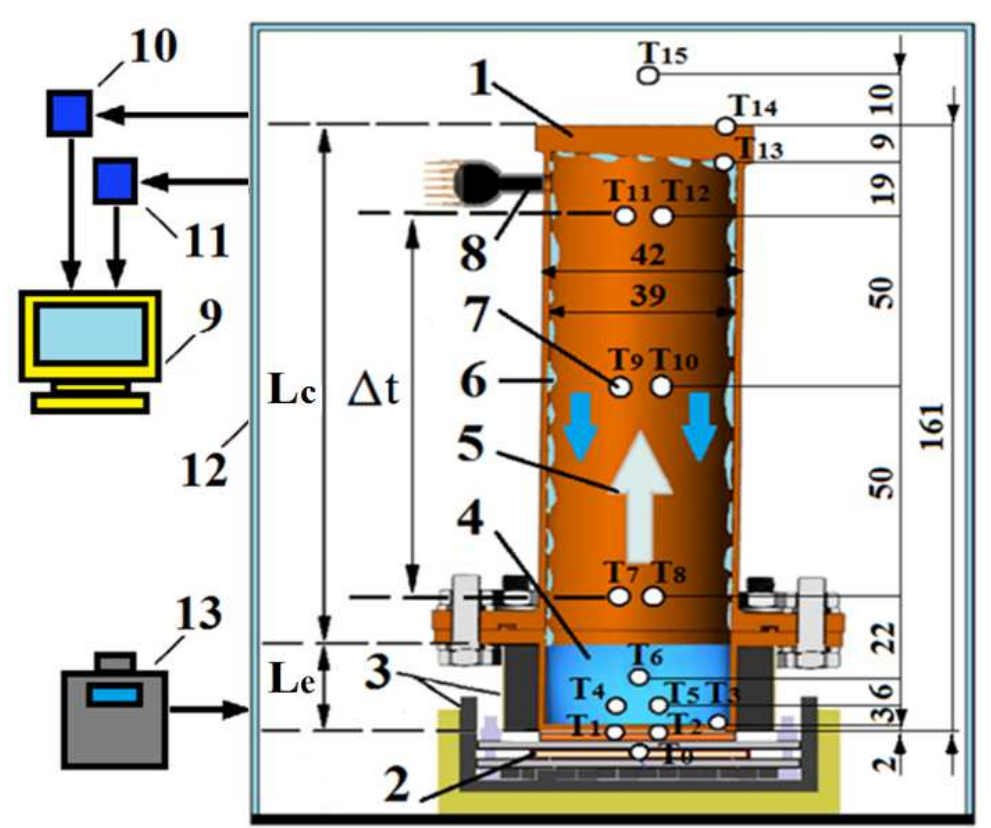

Fig. 1. The principal scheme of the experimental setup: 1 - thermosyphon; 2 - heater; 3 - heat insulation; 4 - coolant; 5 - steam; 6 - condensate; 7 - thermocouples $\left(\mathrm{T}_{0}-\mathrm{T}_{15}\right) ; 8$ - pressure sensor; 9 - personal computer; 10 - NI 9214 analog-digital modular converter; 11 - NI USB-6000 analog-todigital modular converter; 12 - glass box; 13 - laboratory transformer; Le and Lc are the lengths of the evaporative and condensation parts.

The thermosyphon (Fig. 1) (height is $L=161 \mathrm{~mm}$, ratio of external diameter to inner diameter is $d_{e x} / d_{i n}=42 / 39 \mathrm{~mm}$ ) is made of copper, conditionally divided into two parts: evaporative (heat insulated with foamed rubber with $L_{e}=21 \mathrm{~mm}$ ) and condensation (uninsulated with $L_{c}=140 \mathrm{~mm}$ ). The operating principle of the setup (Fig. 1) is given in detail in [19].

It is known [20] that the boiling process in a thermosyphon differs from the boiling process in a large volume. When $d_{i n} / L_{e}<1$, it corresponds to the boiling in a small volume, $d_{i n} / L_{e}>2$ is for the boiling in a large volume.

In the present work $d_{i n} / L_{e}=0.039 / 0.021=1.86$, the physical processes taking place in the thermosyphon are carried out under cramped conditions, but are maximally approximated to the boiling conditions in a large volume.

It was found that the divergence between the values of the critical heat flux obtained on the basis of: 1) the theoretical contributions of the occurrence of a "flooding" [10] regime in the thermosyphon is $92 \%$; 2) S. S. Kutateladze hydrodynamic theory of the heat transfer crisis during boiling is $27 \%$.

The results of the critical heat flux calculation for the experimental setup developed are shown in Table 1 (with the following parameters: $d_{i n}=0.039 \mathrm{~m} ; L_{e}=0.021 \mathrm{M}$; $\rho_{l}=958.1 \mathrm{~kg} / \mathrm{m}^{3} ; \quad \rho_{v}=0.597 \mathrm{~kg} / \mathrm{m}^{3} ; \quad \mu_{l}=0.000279 \mathrm{~Pa} \cdot \mathrm{sec} ; \quad g=9.81 \mathrm{~m} / \mathrm{sec}^{2} ;$ $r=2260000 \mathrm{~J} / \mathrm{kg} ; \sigma=0.05904 \mathrm{~N} / \mathrm{m} ; B o=15.56)$. 
Table 1. Critical heat flux.

\begin{tabular}{|c|c|}
\hline Dependences from references used on the basis of: & $q_{c r}, \frac{k W}{m^{2}}$ \\
\hline \multicolumn{2}{|c|}{$\begin{array}{c}\text { theoretical contributions of the occurrence of a "flooding" regime } \\
\text { in a thermosyphon }\end{array}$} \\
\hline $\begin{array}{l}\text { A. Barnard, F. R. Dell, R. A. Stinchcombe [7]; } \\
\text { Z. Nejat [8] }\end{array}$ & 1013.0 \\
\hline R. K. Sakhuja [9]; G. B. Wallis [10] & 1390.3 \\
\hline O. L. Pushkina, Yu. L. Sorokin [11] & 12605.7 \\
\hline C. L. Tien, K. S. Chung [12] & 5403.4 \\
\hline \multicolumn{2}{|c|}{$\begin{array}{c}\text { S.S. Kutateladze hydrodynamic theory of the heat transfer crisis } \\
\text { during boiling }\end{array}$} \\
\hline H. Imura, K. Sasaguchi, H. Kozai, S. Numata [2] & 1345.2 \\
\hline Y. Haramura; Y. Katto [3] & 1105.3 \\
\hline J. H. Lenhard; V. K. Dhir [4] & 1263.8 \\
\hline V. M. Borishanskiy [5] & 1207.8 \\
\hline E. E. Kazakova [6] & 1016.8 \\
\hline S.S. Kutateladze [13] & 1355.8 \\
\hline B. P. Avksentyuk; S. S. Kutateladze [14] & 1186.3 \\
\hline N. Zuber [15] & 1157.1 \\
\hline W. M. Rohsenow, P. Grifts [16] & 1356.3 \\
\hline I. Mudawar, A. H. Howard, C. O. Gersey [17] & 1279.5 \\
\hline C. K.Guan, J. F. Klausner, R. Mei [18] & 990.6 \\
\hline
\end{tabular}

The average value of the critical heat flux obtained from thirteen correlations with the exception of the dependencies O. L. Pushkina, Yu. L. Sorokin [11] and C. L. Tien, K. S. Chung [12], for the closed two-phase thermosyphon experimental setup is $q_{c r . m .}=1218.4 \frac{\mathrm{kW}}{\mathrm{m}^{2}}$. The error in determining $q_{c r}$ by formula of B P. Avksentyuk; S. S.

Kutateladze [14] does not exceed 3\%. The minimum error (less than 1\%) was obtained in the calculation using the formula of V. M. Borishanskiy [5]. It should be noted that this is the only correlation from the formulas presented which takes into account the liquid viscosity influence on the critical heat flux.

It is possible to determine CHF based on the theoretical contributions of the occurrence of a "flooding" regime in a thermosyphon by using correlations based on the Wallis numbers [7-10] (the dependences are based on the balance of inertial and hydrostatic forces). Correlations based on Kutateladze numbers [11-12] (based on the balance of dynamic forces, surface tension and gravity forces) can not be used for the experimental setup developed. Large deviation of O. L. Pushkina, Yu. L. Sorokin [11] and C. L. Tien, K. S. Chung [12] dependencies, most likely, was due to the fact that in the formulas derivation it was assumed that there was no influence of any vertical channel geometric characteristic on the CHF. Adequate values of critical heat fluxes $\left(950-1400 \mathrm{~kW} / \mathrm{m}^{2}\right)$ at atmospheric pressure, according to the dependencies can be obtained for longer thermosyphons $\left(0.15<d_{i n} / L_{e}<0.45\right)$.

\section{Conclusion}

It is established that in order to calculate the critical heat flux in closed two-phase thermosyphons with the ratio of their internal diameter to the length of the heat supply zone in the range of $1<d_{\text {внут }} / L_{u}<2$, formulas based on the theory of the heat transfer crisis 
during boiling are recommended. In experimental studies conducted on relatively small $\left(1<d_{\text {внут }} / L_{u}<2\right)$ closed two-phase thermosyphons filled with liquid at atmospheric pressure, the authors recommended to use the stability criteria developed by V. M. Borishansky and S. S. Kutateladze.

It is established that formulas based on Kutateladze numbers in the theory of "flooding" are suitable for determining the critical heat flux during liquid boiling in longer thermosyphons $\left(0.15<d_{\text {in }} / L_{e}<0.45\right)$.

This work was carried out at the Kutateladze Institute of Thermophysics SB RAS and financially supported by the Russian Science Foundation (project number 15-19-10025).

\section{References}

1. S. S. Kutateladze, Fundamentals of the heat transfer theory (Atomizdat, Moscow, 1979) [in Russian]

2. H. Imura, K. Sasaguchi, H. Kosai, S. Namata, Int. J. Heat Mass Transfer. 26, 1181 (1983)

3. Y. Haramura, Y. Katto, International Journal of Heat and Mass Transfer 26, 389 (1983)

4. J. H. Lienhard, V. K. Dhir, Journal of Heat Transfer 95, 152 (1973)

5. V.M. Borishanskiy, Technical Physics. The Russian Journal of Applied Physics 26, 452 (1956) [in Russian]

6. E.A. Kazakova, Izvestiya AN SSSR. OTN 1, 64 (1949) [in Russian]

7. A. Barnard, F. R. Dell, R. A. Stinchcombe, UKAEA, AERE-R 7726 (1974)

8. Z. Nejat, Int. J. Multiph. Flow 7, 321 (1981)

9. R. K. Sakhuja, Flooding constraint in wickless heat pipes (axial heat flux limitations) (American Society of Mechanical Engineers, Detroit, 1973)

10. G. B. Wallis, Flooding velocities for air and water in vertical tubes (AEEW, Report R123, England, 1961)

11. O.L. Pushkina, Y.L. Sorokin, Heat Transfer Soviet Research 1, 56 (1969)

12. C.L. Tien, K.S. Chung, AIAA J. 17, 643 (1978)

13. S. S. Kutateladze, Izvestiya AN SSSR. OTN. 4, 529 (1951) [in Russian]

14. B. P. Avksentyuk, S. S. Kutateladze, High Temp. 15, 115 (1977) [in Russian]

15. N. Zuber, Trans. Of ASME. J. Heat Transfer 80, 711 (1958)

16. W.M. Rohsenow, P. Griffith, Chem. Eng. Prog. Symp. Ser. 52, 47 (1955)

17. I. Mudawar, A. H. Howard, C. O. Gersey, International journal of heat and mass transfer 40, 2327 (1997)

18. C. K. Guan, J. F. Klausner, R. Mei, International Journal of Heat and Mass Transfer 54, 3960 (2011)

19. K. O. Ponomarev, S. R. Gupta, E. G. Orlova, D. V. Feoktistov, MATEC Web Conf. 141, 1412017 (2017)

20. I. L. Pioro, Industrial Heat Engineering 7, 24 (1985) [in Russian] 